\title{
Motoric Ability and Nutrition Status Factor Analysis with the Learning Outcomes Playing Skill of Volley Ball
}

\section{Yuni Astuti and Alfiqroam Kumar}

Universitas Negeri Padang

\section{Abstract}

The aims of this study to describe dominan factor on influence learning outcomes playing skill of volley ball in elementary schools. Due to quantitative approach, Motoric ability and nutritional status is the main factors using correlational methode analysis. This research was conducted on Governance Elementary School in Pariaman city. Collected data measured the motor skills, body weight and tall of students to find those corelation with nutritional status. Data analysis techniques was used product moment correlation

Corresponding Author:

Yuni Astuti

yuniastuti@bunghatta.ac.id

Received: 18 January 2019 Accepted: 24 March 2019 Published: 31 March 2019

Publishing services provided by Knowledge E

(c) Yuni Astuti and Alfiqroam Kumar. This article is distributed under the terms of the

Commons Attribution License, which permits unrestricted use and redistribution provided that the original author and source are credited.

Selection and Peer-review under the responsibility of the First ELEHIC Conference Committee.

\section{G OPEN ACCESS} analysiswhich to find ontribution between independent variables with the dependent variable. Based on the results of data analysis found that: 1) There was a significant relationship between the variable motor skills and the learning outcomes of students playing volleyball skills with the finding of $\left.r_{\text {count }} 0.445>r_{\text {table }} 0.361,2\right)$ There was a significant relationship between variables of nutritional status with the results of learning volleyball skills of students with found a $r_{\text {count }}$ of $0.384>r_{\text {table }} 0.361$, thus it can be concluded that the variable motor skills is the most dominant factor in determining the learning outcomes of students playing volleyball skills in elementary schools.

Keywords: motor skills, nutritional status, learning outcomes of volleyball skills

\section{Introduction}

National development policies increasingly provide greater space for the public interest, especially in the field of sports, thus the challenges to development in the field of sports are becoming increasingly server. Physical education and sports are an integral part of education that can make a valuable contribution to the growth, development and development of a whole person. In the education curriculum in Indonesia, Physical Education and Sports are taught at all levels of education, starting from elementary school to high school., in every level of education it is expected to help the government in fostering and developing sports. This will certainly lead to quality Indonesian people in accordance with the National Education System Law. [1] stated that exercise 
activities will help the body stay in shape because training the bones remains strong, encourages the heart to work optimally, and helps eliminate free radicals that roam in the body. So thus it is very important to exercise from an early age or since elementary school. Elementary Schools 10 Paguah Duku Nansabaris Padang Pariaman is an official government-owned educational institution to foster students in developing sports in Padang Pariaman. Through physical education and sports this is an important part of the educational process. This means that through learning physical education and sports that are well directed, children will develop skills that are useful for filling leisure time, engaging in conducive activities. [2] Said that this early age of all the potential of children needs to be encouraged so that the character of children will develop optimally. Furthermore, [3] suggested that: "the implementation of physical education, sports and health is a long-term investment in efforts to improve the quality of Indonesian human resources". Furthermore, [4] explained in more detail that: "Physical education learning in elementary schools must be adjusted according to character, age, and movement ability". One of the sports included in physical education and sports learning material is mini volleyball. "The technique of playing mini volleyball that is learned in elementary school is the same as the technique given to adults and only given in forms of training that are adapted to the characteristics of elementary school children who like to play"[5].

Mini volleyball a sports game that is available in physical education learning materials in elementary schools, which is given to students in grades IV to class VI. Mini volleyball learning materials, both mini volleyball knowledge about rules, field size and so on, are also taught basic technical skills to play volleyball. The technical skills of mini volleyball games taught to students are the basic skills of playing mini volleyball including under passing, over passing, servicing, smash and blocking techniques. Learning the basic skills of playing volleyball mini is also held at Elementary Schools 10 Paguah Duku Nansabaris, Padang Pariaman Regency. Of course after they learn the basic skills of playing mini volleyball, they are expected to develop and have the ability to play volleyball with good techniques. Because learning is an activity that is carried out consciously or get a number of impressions from the material that has been learned, so there is a change in the individual. "Success in learning is the task of a teacher in achieving the goals of learning",[6].

Based on the observations that the author did, it turned out that many students in grade IV and V did not have the best passing skills. This can be seen when doing high passing and lower passing, the ball often does not arrive at the intended friend, and sometimes the ball loose and falls between two hands or the ball cannot be thrown 
properly. Then there are students who do service but the ball does not reach the opponent's space or does not produce points. To be able to perform volleyball playing skills well many factors influence it. Among these factors is the resistance of arm muscle strength, eye-hand coordination, the flexibility of the fingers, the agility of the student in motion, the ability of the motoric, wrist flexibility, muscle strength of the fingers, sight, balance, sensitivity to controlling the ball, foot attitude, the impulse of the arm and the involvement of the ball with the fingers, the motivation of the students to do the skills, and the nutritional status of the students. [7]"The ability to generate muscular strength is quickly defined as the rate of force development, and integral factor in activities involving stretch-shortening cycles, such as dumping, sprinting, and throwing ". Based on the opinions of previous researchers, it was stated that in order to produce muscular abilities it was necessary to develop strength in order to be able to perform running, jumping and throwing movements. [8] suggested that: the learning process of students in elementary schools should be prioritized on basic developments such as interest in learning, motivation to learn, physical fitness and others, which will later become provisions for the next level. This means that when the basic foundation of students is good, it will have an impact on learning outcomes that are more optimal.

In accordance with the description, it is clear that the problem in this study is the lack of volleyball skills of students of Elementary Schools 10 Paguah Duku Nansabaris, Padang Pariaman Regency, the authors suspect that it has something to do with motor skills, nutritional status and student motivation that is not good. So that students are not right in receiving the ball, and do not move well organized. This causes the imposition of the ball by hand is often incorrect and the return of the ball cannot be performed properly. Guided by the problem described in the background of the problem, the problem can be formulated as follows:

i. Is there a relationship of motor skills with the learning outcomes of volleyball playing skills of students of Elementary Schools 10 Duah Nansabaris, Padang Pariaman Regency?

ii. Is there a relationship between nutritional status and the learning outcomes of volleyball playing skills of students of Elementary Schools 10 Paguah Duku Nansabaris, Padang Pariaman Regency?

Based on the problems that have been formulated above, this study has a purpose for.

i. Analyzing the relationship of motor skills with the learning outcomes of volleyball playing skills students of Elementary Schools 10 Paguah Duku Nansabaris Padang Pariaman Regency? 
ii. Analyzing the relationship of nutritional status with the learning outcomes of volleyball playing skills of students of Elementary Schools 10 Paguah Duku Nansabaris, Padang Pariaman Regency?

\subsection{Learning outcomes for volleyball playing skills}

Learning problems are problems that are always actual and faced by everyone, many experts discuss and produce various theories about learning and similarly, the results of learning volleyball playing skills are always a problem. So that someone can play volleyball first he must master the basic techniques of volleyball. Mastery of techniques in volleyball games is very important, because the art of playing volleyball is seen in players who have mastered high techniques to resemble acrobatics with blows and trickery tricks that will fascinate the audience to watch it. [9] revealed that: "Volleying the ball in a mini volleyball game means bouncing or playing a ball in the air with the aim of directing the ball to fall on the opponent's field as quickly as possible".

Simply put, according to [10]"techniques can be interpreted as ways". Thus, it can be exemplified that service techniques in volleyball games are how a person serves correctly directed to the desired target, and dies in the field of the opponent's game. The basic volleyball technique according to the Indonesian Volleyball Association [28] is "service, top passing, down passing, smash and block". [11] basic techniques in volleyball games are service, under passing and top passing, smash and block ". In learning basic techniques, the game of volleyball taught and trained is bottom service, under passing and over passing. With the mastery of the three basic volleyball techniques, elementary school students can already play volleyball. The following will be explained by each of the basic techniques that students do, namely as follows:

\subsubsection{Lower service technique}

Service is the initial attack of the game or opening blow to start a game. According to [12] that "service that is the initial blow to start a game, in accordance with the improvement in the quality of service play is now an attack to turn off the ball in the opponent's place or so that the opponent cannot receive the ball properly". But in general, the service consists of two, namely the top service and bottom service, in this study the bottom service is seen. The bottom service is the easiest service to do and is suitable for novice players or school students. [13] says that "bottom service is the simplest and easiest service taught especially for beginners and school students, because the movements 
are more natural and do not require too much energy. In performing the service under the hand, hitting the ball may hold or with the palm of the hand open, the knees are slightly bent and weight weight in the center. Then the ball is placed in front of the right shoulder, equal to $10-20 \mathrm{~cm}$, at the same time the right hand is pulled backwards, then swung forward towards the top and hit the back of the ball. Next the arm is straightened by the palm or the hand grip is tightened. After hitting the ball, proceed by moving your body weight forward, by moving your right foot (left) forward and immediately entering the field to take a position with a normal attitude.

\subsubsection{Lower passing technique}

Passing down in a volleyball game is one technique or method with the aim of passing the ball to someone you want in a game. This bottom passing technique is always used in playing volleyball, both for adults and for children of primary school age. This under passing must be taught to elementary school children, both in intracuricular learning and extracurricular learning in mini volleyball.

[14] said that "passing is passing the ball to one's own friends in a team with a certain technique, as a first step to compile an attack pattern on the opposing team". That means passing in a volleyball game is passing the ball to a friend in a team. [15] said that "down passing is the main element to defend the team from the opponent's attack (the ball that comes too hard and is difficult to play with top passing, then taken with a lower passing). In addition to maintaining, it also plays a role in building attacks. "

\subsubsection{Upper passing technique}

The top pass in the volleyball game is one technique that is often used to pass the ball to a friend in a team with the aim of presenting the ball as best as possible, for example on the net, then the ball is hit with a smash technique. the first step is to arrange the attack pattern to the opposing team. [16] says "passing over is an important element in the game of volleyball. Mastery of good passing techniques, will determine the success of a team to build attacks well. What's more done in a variety of ways, all the potential for team attack can be utilized". 


\subsection{Motor ability}

In the physical education environment, sports motor skills need to be discussed, because they are part of the psychomotor domain, and development is expected to be the mastery of motor skills in certain sports. "Motor learning taught in schools is also interpreted as a series of processes related to training or briefing cause changes in the ability of individuals (students) to be able to display highly skilled movements "[17]. Thus it can be said that motor skills are skills, strength, and ability to do something. "Motor physical development especially the balance of the child's body also includes efforts to optimize the growth and development of the child's body through the types of play activities that support"[18].

While the meaning of motor skills is stated by [19], namely "the capacity of a person in moving is seen from physical and physical power that refers to muscle". Thus it is clear that motor skills are the quality of one's ability (individual) in carrying out movements which are seen as the basis for success in completing motion skills. Someone who has high motor skills, is expected to be more successful in completing special motor skills tasks. Because motor skills are the quality of a person's ability to facilitate movement skills.

This motor ability can be increased through sports exercises and play activities that are often carried out by children of elementary school age. Playing activity is a spontaneous activity of childhood that connects it to adult activities. In its activities involve the environment, imagination, the appearance of the child by using all feelings, hands or the whole body. [20] classifies the stages of motor skills of students in grades $\mathrm{V}$ and VI (age 10-12 years) Primary school as follows:

"1) Recreational activities; develop knowledge of skills in games and activities, useful social skills for later life, and show social leadership activities to be good examples 2) aquatics: diving and swimming skills in various styles, endurance, coordination between arms and legs, there is improvement in breathing. 3) games and sports: developing the basis of play and motion, coordination. 4) rhythmic activity: balance, able to display basic steps, developing skills, manners, physical abilities, developing limb coordination, arms. 5) development activities: improvement of the strength of the shoulders, back and limbs, correcting the lack of muscle strength if possible with a high frequency of exercise, improvement of physical fitness parameters. 6) self-testing: better body shape and strength and developing muscle coordination, protection of recreation time and reflexes, better courage and physical self". 
Based on the above quotation, it can be concluded that the grouping of motor skills in elementary school students at the age of 10-12 years can be developed such as rhythmic, aquatic, game and sports activities and recreational activities. All of this will increase knowledge and experience. Various sports skills can increase muscle strength, muscle endurance, coordination of movement, speed and accuracy and are useful in everyday life. Children who have good motor skills, they are trained in displaying attitudes to others, he is able to apply courtesy, socialize with friends. Furthermore, through the motion activities they do will be able to improve physical fitness and physical fitness will be better.

[21] suggests that a person's ability to master sports motor skills is different, the difference is determined by: "the ability of conditions and coordination possessed, age differences, experience of movement, gender, frequency of exercise, differences in goals and motivation in learning motor skills and differences in cognitive abilities". The development of motor skills is largely determined by two factors of growth and development. Both of these factors must be supported by training in accordance with the child's maturity and good nutrition. Growth is meant here is a quantitative change of body organs that can be measured in length ( $\mathrm{cm}=$ centimeters), in weight $(\mathrm{kg}=$ kilogram) or in the size of the content. While development is a process of change towards a better direction. In another sense is a qualitative change for example related to personality, psychic and changes in muscle function for the better.

According to [22] that "motor development will not stop at certain elements, but will run continuously from before birth so that the person dies". Thus it can be interpreted that a person's motor development is not limited, because the motoric development is continuous, but its development can be rapidly improved through sports activities such as playing activities or by playing method approach. Elements and factors that affect motor skills according to [23] elements of motor skills namely "strength, endurance, speed, balance, agility, endurance and coordination of movement". Furthermore, [24] said the elements contained in motor skills are "strength, coordination, speed, balance and agility that can be developed fully through an exercise program".

\subsection{Nutritional status}

The application of nutrition to children is important, especially for children of primary school age, in the period of development and growth. Nutrition is closely related to food consumed by a person, nutritional needs must be met so that this can be beneficial to health and fitness, as well as physical readiness of students in the process of learning 
physical education, and sports whose activities require energy or energy. [25] argues that: "Nutrition and health greatly affect children's development. Nutritional deficiencies can cause the child's growth to become sluggish, lacking power and inactivity. Conversely, children who get nutritious food, supportive environment, parental treatment and good living habits will support children's growth and development ".

Nutrition is defined as a process of organisms using food consumed normally through the process of digestion, absorption, transportation, storage of metabolism and expenditure of nutrients to maintain life, growth and normal function of organs and produce energy. According to [30] nutritional status is "The state of the body as a result of consumption, absorption and use of food in the body". In accordance with the above opinion, it can be concluded that the amount and food consumed by someone is an indicator of their nutritional status. The energy needed for physical performance is obtained from the metabolism of foodstuffs consumed daily, so that food or nutrients are one of the determinants of the quality of physical performance and growth of children, especially the quality of physical work of students, in following the physical and sports physical education learning process.

Food regulation to meet balanced nutritional needs is important for students, given the importance of the development of each nutrient for the body as a whole. The nutritional needs of each person are different, this is due to differences in physical activities / activities and psychological conditions. But general guidelines for balanced nutrition (PUGS) are a description of the perfect four healthy five pattern. Furthermore, consuming a variety of foods is very beneficial for health. Diverse foods mean foods that contain many nutrients needed by the body. Furthermore, nutrients are compounds or chemical elements contained in food and are needed for normal metabolism in the body Nutrients needed by the body include: carbohydrates, proteins, fats, minerals, vitamins and water.

Balanced nutrition for students in conducting various learning activities at school, and activities to fill their free time by playing. This means that it is very important for balanced nutrition for children of primary school age, especially when they are in a period of development and growth, specifically meeting sufficient energy needs to carry out their activities. [29] says that: "Energy is needed by the body first to maintain the basic functions of the body which is called basal metabolism by 60-70 percent of total energy needs. In a state of total rest but not sleeping in a comfortable temperature environment and a calm atmosphere, the body needs other body functions such as digestion, walking, work and other activities. "Based on the above opinion, it can be concluded that for children of school age Basics that are happy, and like to play are 
of course very important meaning energy for the needs of the body. This is mainly in maintaining basic body functions or alkaline metabolism, in addition to other activities.

\section{Method}

The model used in the study is correlational research which aims to see the relationship between independent variables and dependent variables. Samples in this study are fourth and fifth grade students of Elementary Schools 10 Paguah Duku Nansabaris, Padang Pariaman Regency, totaling 30 people. The research design used in this study is to use product moment correlation, then if there is a relationship then proceed with regression or prediction when knowing the score on one variable, the score on the second variable can be predicted. Data collection techniques in this study are measuring on motor skills, nutritional status and learning outcomes of students playing volleyball skills. Data analysis techniques used are simple correlation analysis techniques and multiple correlations. Before analyzing data, the analysis of the analysis requirements is the Normality test to find out whether the data comes from a population that is normally distributed, carried out by the Lilliefors Test.

\section{Research Result}

\subsection{Motor ability}

The results of the variable motor skills of 30 students in Elementary Schools 10 Paguah Duku Nan sabaris, Padang Pariaman Regency, obtained the highest score obtained by students was 66.93 and the lowest score was 36.18. While the range (measurement distance) from the results of the student's motor skills data is 30.75. Based on group data that has been stated above for students' motor skills variable in Elementary Schools 10 Paguah Duku Nansabaris, Padang Pariaman Regency, the mean value is 50 and the median is 51.56. While the standard deviation (standard deviation) is 8.67. Furthermore, the frequency distribution of the results of motoric ability data at Elementary Schools 10 Paguah Duku Nansabaris, Padang Pariaman Regency can be seen in table 1.

Guided by Table 1 above, it is clear that out of 30 students who have the results of motor skills, for the interval class $<36.99$ is 2 people (6.45\%), interval classes 36.99 45.66 are 8 people (25.81\%) and interval classes $45.67-54.33$, namely 13 people (41.93\%). While the interval class $54.34-63.00$ is 5 people (16.13\%) and interval class $>63.00$ is 3 people $(9.68 \%)$. Based on the results of the data on the variable motor skills of students 
TABLE 1: Frequency Distribution of Motoric Capability Data Results.

Relative Frequency
$>63,00$
$54,33-63,00$
$45,67-54,33$
$36,99-45,66$
$<36,99$
amount

\begin{tabular}{|c|}
\hline $\begin{array}{c}\text { Frequency } \\
\text { Absolute }\end{array}$ \\
\hline 3 \\
\hline 5 \\
\hline 13 \\
\hline 8 \\
\hline 2 \\
\hline 31
\end{tabular}

\begin{tabular}{|c|}
\hline Interval Class \\
\hline 9,68 \\
16,13 \\
41,93 \\
25,81 \\
6,45 \\
100 \\
\hline
\end{tabular}

in Elementary Schools 10 Paguah Duku Nan sabaris, Padang Pariaman Regency which have been stated on the previous page, it can be concluded that students who have motor skills with scores above the group on average are 14 people $(45,16 \%)$ and the average score in the group no one has it. While for the score below the group the average is 17 people (54.84\%).

\subsubsection{Nutritional status}

Based on the results of the measurement of nutritional status carried out on 30 elementary school students, obtained the nutritional status with the highest score was 131 and the lowest score was 79. While the range (distance measurement) was 52. Based on the group data the mean count was 101,83 , median value 105.4 , and standard deviation (standard deviation) is 12.43 .

TABLE 2: Frequency Distribution Results of Data on Variable Nutritional Status.

\begin{tabular}{l|c|}
\hline Interval Class & Category \\
\hline$>90 \%$ & Good \\
\hline $81 \%-90 \%$ & Less \\
\hline$\leq 80 \%$ & Bad \\
\hline amount & \\
\hline
\end{tabular}

\begin{tabular}{|c|}
\hline $\begin{array}{c}\text { Absolute } \\
\text { Frequency }\end{array}$ \\
\hline 23 \\
\hline 5 \\
\hline 2 \\
\hline 30 \\
\hline
\end{tabular}

\begin{tabular}{|c|}
\hline $\begin{array}{c}\text { Relative } \\
\text { Frequency }\end{array}$ \\
\hline 76,67 \\
\hline 16,67 \\
\hline 6,67 \\
\hline 100 \\
\hline
\end{tabular}

Based on Table 2 above, it can be concluded that out of 30 people who have good nutritional status, there are 23 people (76.67\%) and nutritional status in the low category, namely 5 people (16.67\%). While the nutritional status is in the poor category, there are 2 people (6.67\%). Based on the results of the data presented above, it can be concluded that students who have nutritional status, for the score above the group on average is as many as 15 people (50\%) and nutritional status with an average score in the group 
none of the students have it. Whereas for the group score below the average that is as many as 15 people (50\%).

\subsection{Learning outcomes for volleyball playing skills}

The data of the volleyball playing skills results from 30 students, found the highest score was 67 and the lowest score was 40, while the range (distance of measurement) 28 . The distribution of scores resulted in an average count of 50.00, median) 53.31 and standard deviation (standard deviation) 8.43.

TABLE 3: Frequency Distribution of Results of Learning Results Data on Volleyball Skills.

Kelas Interval
$62-67$
$56-61$
$50-55$
$44-49$
$38-43$
Jumlah

\begin{tabular}{|c|}
\hline Frekuensi Absolut \\
\hline 4 \\
\hline 4 \\
\hline 6 \\
\hline 7 \\
\hline 9 \\
30 \\
\hline
\end{tabular}

\begin{tabular}{|c|}
\hline Frekuensi Relatif \\
\hline 13,33 \\
13,33 \\
20 \\
23,33 \\
30 \\
100 \\
\hline
\end{tabular}

Guided by the previous table, out of 30 students who were used as samples in this study, who were in interval classes 38-43, there were 9 people (30\%), interval classes 44-49, there were 7 people (23.33\%) and interval classes 50-55, namely as many as 6 people (20\%). Furthermore, for interval classes 56-61, there were 4 people (13.33\%) and interval classes 62-67, there were also 4 people (13.33\%). Based on the results of volleyball playing skills data that have been stated on the previous page, it can be concluded that students who have volleyball playing skills with scores above the group average are 12 people (40\%) and for scores in the average group that is 2 people (6.67\%). As for volleyball playing skills with a score below the average group of 16 people (53.33\%).

\subsection{Analysis requirements test}

Before testing the hypotheses proposed in this study, the analysis requirements are first tested by testing the normality of the data to determine whether the data from the variables studied are normally distributed or cannot be used by the Lilliefors test.

Based on table 4 above, it turns out that the results of the Lilliefors test are observed by $L<L t$, if $L_{\text {observation }}$ is smaller than $L_{\text {table }}$, this means that the three variables studied in this study are normally distributed. 
TABLE 4: Summary of Data Normality Test.

\section{Variabel}

Motor Ability (X2)

Nutritional Status (X2)

Learning Outcomes for Bollywood Playing Skills (Y)

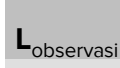

0,125

0,128

0,032

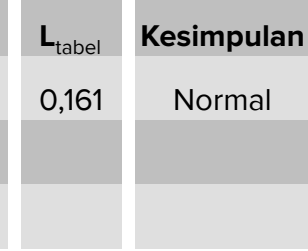

\subsection{Hypothesis testing}

The first hypothesis proposed in this study is that there is a relationship between motor skills and the results of learning the volleyball playing skills of students at Elementary Schools 10 Paguah Duku Nansabaris, Padang Pariaman Regency. To see the magnitude of the correlation coefficient is to use the product moment correlation analysis and to test the significance (significant) of the correlation coefficient followed by the correlation t test.

Based on the results of the correlation analysis between motor skills $\left(X_{1}\right)$ with the results of learning volleyball skills $(Y)$ obtained $r_{\text {count }}$ of $0.445>r_{\text {table }} 0.361$, meaning that there is a relationship between motor skills and learning outcomes of students playing skills in Elementary Schools 10 Paguah Duku Nansabaris Padang Pariaman Regency. To test the significant correlation coefficients between motor skills and the learning outcomes of students' playing skills at Elementary Schools 10 Paguah Duku Nansabaris, Padang Pariaman Regency, t-test was carried out. For more details the results of the t-test summary or test the correlation coefficient can be seen in table 5 .

TABLE 5: Summary of Tests of Significance of Correlation Coefficients.

\begin{tabular}{|l|c|c|c|}
\hline Variable & $\mathrm{T}_{\text {count }}$ & $\mathrm{t}_{\text {table }} \alpha=0.05$ & Conclusion \\
\hline $\mathrm{X}$ and $\mathrm{Y}$ & 2,63 & 1,70 & Significant \\
\hline
\end{tabular}

Furthermore, to find out the magnitude of the contribution of motor skills to the learning outcomes of volleyball playing skills, using the determinant formula $r 2 \times 100 \%=$ $0.4452 \times 100 \%=19.80 \%$. This means that the contribution of motor skills $(X 1)$ to the learning outcomes $(\mathrm{Y})$ of students in Elementary Schools 10 Paguah Duku Nansabaris, Padang Pariaman Regency is $19.80 \%$.

\subsection{The second hypothesis}

proposed in this study is that there is a relationship between nutritional status and the results of learning the volleyball playing skills of students at Elementary Schools 
10 Paguah Duku Nansabaris, Padang Pariaman Regency. To see the magnitude of the correlation coefficient is to use the product moment correlation analysis and to test the significance (significant) of the correlation coefficient followed by the correlation $t$ test.

Based on the results of the correlation analysis between nutritional status $\left(\mathrm{X}_{2}\right)$ with the results of learning volleyball skills $(Y)$ obtained $r$ count $0.384>r$ table 0.361 , meaning that there is a relationship between gizid status and learning outcomes of students playing skills in Elementary Schools 10 Paguah Duku Nansabaris, Padang Pariaman Regency. To test the significant correlation coefficients between nutritional status and the results of learning the volleyball playing skills students in Elementary Schools 10 Paguah Duku Nansabaris in Padang Pariaman Regency carried out a t test. For more details the results of the t-test summary or test the correlation coefficient can be seen in table 6 .

TABLE 6: Summary of Test of Significance of Correlation Coefficients.

\begin{tabular}{|c|c|c|c|}
\hline Variabel & $\mathrm{t}_{\text {count }}$ & $\mathrm{t}_{\text {table }} \alpha=0.05$ & Conclusion \\
\hline $\mathrm{X}$ and $\mathrm{Y}$ & 2,20 & 1,70 & Significant \\
\hline
\end{tabular}

Furthermore, to find out the magnitude of the contribution of giziter status to the learning outcomes of volleyball playing skills, by using the determinant formula of $r 2$ $\times 100 \%=0.3842 \times 100 \%=14.75 \%$. This means that the contribution of motor skills (X1) to the learning outcomes (Y) of students in Elementary Schools 10 Paguah Duku Nansabaris, Padang Pariaman Regency is $14.75 \%$.

\section{Discussion}

Based on the results of the study which states that there is a significant relationship of motor skills with learning outcomes of volleyball playing skills students in Elementary Schools 10 Paguah Duku Nansabaris, Padang Pariaman Regency, and their contribution is 19.80 percent, and empirically accepted the truth. Thus it can be interpreted that the higher the motor skills of students, the higher the learning outcomes of volleyball playing skills of students. [27] say that motor skills are "a person's capacity to move seen from physical and physical power that refers to muscles". This means that the capacity of students to move in physical education is seen from the physical appearance that refers to the muscles. Some experts even say that motor skills as a quality of one's ability can facilitate movement skills.

In accordance with the explanation above, then students who have high motor skills, they will have the physical quality shown very well. In another sense the quality of the ability of a student (individual) in carrying out a movement that is seen as the foundation 
of success for completing motion skills. Thus it can be said that students who have high motor skills are expected to be more successful in completing special motor skills tasks, especially in completing various skills in sports physical education.

Other factors that influence the learning outcomes of students' volleyball playing skills are nutritional status. Contribution of nutritional status with the results of learning the volleyball playing skills of students in Elementary Schools 10 Paguah Duku Nansabaris, Padang Pariaman Regency, and the contribution of 14.75 percent, and the empirical truth is accepted. This means that if students have a good nutritional statuz, it will indirectly improve the learning outcomes of students playing volleyball skills at school. According to [30] nutritional status is "the state of the body as a result of consumption, absorption and use of food in the body."In accordance with the above opinion, it can be concluded that the amount and food consumed by someone is an indicator of their nutritional status. The energy needed for physical performance is obtained from the metabolism of foodstuffs consumed daily, so that food or nutrients are one of the determinants of the quality of physical performance and growth of children, especially the quality of physical work of students, in following the physical and sports physical education learning process.

\section{Conclusion}

i. There is a significant relationship between motor skills and learning outcomes of volleyball playing skills of students in Elementary Schools 10 Paguah Duku Nansabaris, Padang Pariaman Regency, with found $t_{\text {count }} 2.63>r_{\text {table }} 1.70$ and the contribution of 19.80 percent, and the correctness received empirical.

ii. There is a significant relationship between tatus nutrition and the results of learning the volleyball playing skills of students at Elementary Schools 10 Paguah Duku Nansabaris, Padang Pariaman Regency, with found $t_{\text {count }} 2.20>r_{\text {table }} 1.70$ and the contribution of 14.75 percent, and the truth empirically

\section{References}

[1] Astuti, Y., \& Mardius, A. (2017). Development of Collaborative Games in Optimizing Character Formation of the Teaching and Education Faculty, Bung Hatta University, Padang. Journal of Physical Education and Sports. 9 (2), 79-86.

[2] Astuti, Y., \& Mardius, A. (2017). Development of Collaborative Games in Optimizing Character Formation of the Teaching and Education Faculty, Bung Hatta University, 
Padang. Journal of Physical Education and Sports. 9 (2), 79-86.

[3] Kurniawan, W.D \& Hartati, C.Y (2014). Application of Modification of Bolavoli Games to Improve the Effectiveness of Physical Education, Sport and Health Learning (A Study on Class Viii Students in Gedangan 1 Public Middle School, Sidoarjo. Journal of Sports Education and Health. 2 (1). 14-19.

[4] Purnama, D.D \& Indahwati N. (2014.). Improved Service Learning Outcomes Under Bolavoli Through Sponge Ball Media in Class V A Students of SDN Kedurus III Surabaya. Journal of Sports Education and Health. 2 (1), 253-258.

[5] Astuti Yuni. (2017). The Influence of Drill Methods and Playing Methods on Mini Volleyball Playing Skills (Experimental Study on Students of 14th Village in Jambak, Koto Tangah SubRegency, Padang City), Al Ibtida: Journal of MI Teacher Education. (4), 1-16.

[6] Cahyanto, A. G \& Hidayat, T. Influence of Game Modification on Learning Outcomes for Bollywood (Study of Viic Students in Junior High School 1 in Sidoarjo Regency). Journal of Physical Education. 2 (2), 691-695.

[7] Kruse, N. T., Barr, M. W., Gilders, R. M., Kushnick, M. R., \& Rana, S. R. (2015). Effect Of Different Stretching Strategies On The Kinetics Of Vertical Jumping In Female Volleyball Athletes. Journal of Sport And Health Science, 4 (4), 364-370. Https://Doi. Org/10.1016/J.Jshs.2014.06.003

[8] Rokhayati, A., Nur, L., \& Gandana, G. (2016). Implementation of a Tactical Approach in Physical Education Learning Against Motivation, Physical Fitness and Motor Ability. Journal of Physical Education and Sports. 1 (2), 57-67.

[9] Harjono, A. T \& Pardijono. (2015). Application of Volleyball Games Can Improve Student Movement Activities (Study in Class V Students at SDN Margorejo V / 407). Journal of Sports Education and Health. 3 (3). 631 - 634.

[10] Syafruddin. (2011). Sports Coaching Science. Padang: UNP Press.

[11] Syafruddin. (2011). Sports Coaching Science. Padang: UNP Press.

[12] Erianti. (2011). Volleyball. Padang: Sukabina Press.

[13] Bachtiar. (1999). Knowledge of Volleyball Game Basics. Padang: FIK UNP.

[14] Erianti. (2011). Volleyball. Padang: Sukabina Press

[15] Margiyani. (2008). Sports and Health Physical Education 4 SD / MI. Jakarta: Bumi Aksara.

[16] Erianti. (2011). Volleyball. Padang: Sukabina Press

[17] Erianti. (2011). Volleyball. Padang: Sukabina Press 
[18] Manalu Warti. (2017). The Influence of Learning Methods and Learning Motivation on Sprint Learning Outcomes. Journal of Physical Education and Sports. 9 (2).

[19] Pratiwi, Y., \& Kristanto, M. (2015). Efforts to Increase Children's Independence through Character Pillar 2 Media at Tk B in Ra Pelangi Nusantara 02 Semarang Academic Year 2013/2014. Paudia Research Journal, 18-39. Retrieved From http://Google.Schoolar. Com/.

[20] Mutohir, Toho Cholik and Gusril. (2004). Motor Development in Children. Jakarta: Director General of Sports Ministry of National Education.

[21] Sukintaka. (2004). DestinasiPendidikan Jasmani, Jakarta: Ministry of Education and Culture.

[22] Kiram, Yanuar. (2000). Learning Motor. Jakarta: Ministry of Education and Culture.

[23] Sukintaka. (2004). DestinasiPendidikan Jasmani, Jakarta: Ministry of Education and Culture.

[24] Harsono. (1988). Coaching and Psychological Aspects in Coaching. Jakarta: P2LPTK.

[25] Mutohir, Toho Cholik and Gusril. (2004). Motor Development in Children. Jakarta: Director General of Sports Ministry of National Education.

[26] Astyorini, Y. D. (2014). The Relationship of Nutritional Status to Motor Ability of Class 1 Elementary School Children at SDN Krembangan North I / 56 Surabaya. Journal of Sports Health, 2 (2), 33-39.

[27] Mutohir, Toho Cholik and Gusril. (2004). Motor Development in Children. Jakarta: Director General of Sports Ministry of National Education.

[28] PBVSI (2005), Vollyball Game Rules, Jakarta: PBVSI.

[29] Soekirman. (2000). Nutrition Science and its Application for Family and Society. Director General of Higher Education. Jakarta.

[30] Wellis, Wilda dan Syafrizar. (2009). "Student Achievement Index of the Faculty of Sport Sciences, Padang State University Judging from the Nutritional Status Side", Journal of the Education Forum. Vol. 30, No. 02, Agustus 2005, hal. 193. 